\title{
ABANDONO AFETIVO PARENTAL, OS LIMITES COERCITIVOS DO DIREITO E A JUDICIALIZAÇÃO DO AFETO
}

\author{
PARENTAL AFFECTIVE ABANDONMENT, THE COERCITIVE LIMITS OF LAW AND THE \\ JUDICIALIZATION OF AFFECTION
}

\section{Yumara Lúcia Vasconcelos}

\begin{abstract}
Pós doutora em Direitos humanos, doutora em Administração, professora do curso de Administração da UFRPE e docente permanente do PPGDH/UFPE - Programa de pós graduação em Direitos Humanos.

E-mail: yumaravasconcelos@gmail.com
\end{abstract}

Recebido em: 29/02/2020

Aprovado em: 08/10/2020

\begin{abstract}
RESUMO: Pesquisa qualitativa, este estudo objetivou confrontar decisões e posições doutrinárias relativas ao abandono afetivo, com vistas a elaborar um entendimento fundamentado. Juridicamente, a afetividade pode ser considerada um dever parental? Para atingimento desse propósito, optou-se metodologicamente pelo método de estudo multicascos, procedendo-se a uma sistemática análise documental amparada em acórdãos judiciais, sem recorte de procedência, e na literatura especializada. Sem se prestar à finalidade de generalização, a discussão de resultados encaminhou à conclusão da fragilidade do argumento de negativa de afeto como motivo à exigência de reparação por dano moral. Outrossim, revelou a necessidade de se distinguir a ausência de afetividade e desdém acintoso, o que configura prática discriminatória. As análises remetem à relevância de se considerar na avaliação das situações jurídicas, a tipologia do abandono, material e afetivo. A construção do desamor é inacessível a terceiros, não podendo ser controlada socialmente. Tratos motivados exclusivamente por decisões judiciais não dissimulam o que se instala na intimidade da pessoa humana, não desnaturando quem se é verdadeiramente. Enquanto amar é faculdade, o cuidado erige-se como dever. As argumentações postas não remetem à negação da existência do fenômeno-objeto desta pesquisa, questionando-se apenas o alcance do Direito, que segundo o entendimento delineado incide apenas na exterioridade do abandono afetivo. Por essa lógica, trata-se de um vetor primário ou gatilho para outras formas de violação cuja responsabilidade civil é cabível.
\end{abstract}

Palavras-chave: Princípio da afetividade. Dever de cuidado. Abandono afetivo. Constitucionalização.

ABSTRACT: Qualitative research, this study aimed to confront doctrinal decisions and positions related to emotional abandonment, in order to elaborate a grounded understanding. In legal terms, can affection be considered a parental duty? To achieve this purpose, the method of multicase study was chosen methodologically, proceeding to a systematic documentary analysis supported by judicial rulings without source of origin and in the specialized literature. Without lending itself to the purpose of generalization, the discussion of results led to the conclusion that the negation of affection argument was weak as a reason for the claim for compensation for moral damage. 
Moreover, it revealed the need to distinguish the absence of affection and sharp disdain, which constitutes discriminatory practice. The analyzes refer to the relevance of considering in the assessment of legal situations, the type of abandonment, material and affective. The construction of unloving is inaccessible to third parties and cannot be socially controlled. Deals exclusively motivated by judicial decisions do not disguise what settles in the intimacy of the human person, not denaturing who is truly. While love is college, care is built as a duty. The arguments put forward do not refer to the denial of the existence of the object phenomenon of this research, questioning only the scope of the Law, which according to the outlined understanding only affects the externality of emotional abandonment. By this logic, it is a primary vector or trigger for other forms of violation whose civil liability is reasonable.

Keywords: Principle of affectivity. Care obligation. Affective abandonment. Constitutionalization.

SUMÁRIO: Introdução. 1 Dignidade da pessoa humana. 2 Constitucionalização do código civil. 3 Direito, família e afetividade. 4 Abandono afetivo: Análise dos casos. Considerações finais. Referências.

\section{INTRODUÇÃO}

A invocação simbólica do princípio da dignidade humana vincula-se, geralmente, a situações de violação, a despeito da alegação de imprecisão, independentemente dos atores sociais envolvidos. Novos fatos sociais reclamam do Direito, respostas e soluções emergentes às tensões de natureza ética, religiosa, política e cultural, criadas pela própria sociedade. Diretiva metajurídica e imperativo ético-existencial, o princípio da dignidade extrapola o próprio ordenamento porque tem existência independente do Direto, especialmente quando considerada atributo inerente à pessoa humana. Assim, não se limita ao "sujeito virtual", aquele de direito e sujeito da codificação civil, definido abstratamente nas relações jurídicas. Alcança a pessoa concreta em sua existência plena.

“A preservação e a promoção da dignidade da pessoa humana passam, pois, pela disciplina das relações concretas de coexistencialidade. É nessa dimensão que se dá a concretização do princípio da dignidade, que, a seu turno é tarefa do Estado, "de todos e de cada um." (FACHIN e PIANOVSKI, 2008, p. 104)

A racionalidade de sua força normativa repercute em todo sistema jurídico, qual seja, o "mundo do dever - ser" que corresponde àquele próprio do direito, abstração forjada a partir de uma perspectiva eminentemente positivista. Assim, como princípio e regra constitucional, a dignidade se estabelece como pilar fundamental do Estado democrático de Direito. "A inserção do princípio da dignidade da pessoa humana na Constituição não é - e não pode ser tomada como exercício retórico do legislador constituinte: trata-se de norma constitucional que, como tal, é vinculante." (FACHIN e PIANOVSKI, 2008, p.103)

A preservação da dignidade humana é o fim maior de qualquer ordenamento, pois se impõe como imperativo ético-existencial de dúplice dimensão: axiológica e principiológica (princípio e valor). Por conseguinte, sua densidade valorativa, prima facie, tem prevalência material sobre aquela essencialmente normativa. É essa supremacia que fundamenta a tutela e reconhecimento jurídico da personalidade da pessoa humana e, consequentemente, dos direitos subjetivos correspondentes. De fato, o princípio da dignidade oferece ampla proteção à personalidade da pessoa humana, concretizada por meio dos direitos da personalidade e demais institutos jurídicos do Direito Público e Privado. Como consequência direta, todos os institutos do Direito Civil devem preservar e promover a dignidade da pessoa. Dito de outra forma, “(...) todos os institutos fundamentais do Direito Civil devem atender à dignidade da pessoa, desde a 
propriedade funcionalizada, passando pelas relações de família até as obrigacionais, aí incluídos o contrato e a responsabilidade civil.” (FACHIN e PIANOVSKI, 2008, p.105)

De fato, a codificação civil antes da Constituição Federal de 1988, de escopo patrimonial, era alicerçada no conceito de propriedade e atendia primordialmente a burguesia. Essa mudança do eixo de tutela e, por conseguinte, a repersonalização do Direito, deslocou a existência humana para o centro do ordenamento, com prevalência sobre qualquer relação jurídica patrimonial.

Esse giro paradigmático rompeu a tradição de três séculos de concepção de Direito Civil como ordem de proteção do patrimônio ou da propriedade individual, segundo a ideologia triunfante do individualismo jurídico burguês ou liberal. $\mathrm{O}$ patrimonialismo marcante do Direito Civil, expressado na legislação e na doutrina, afastou de sua órbita as relações de caráter privado que não tivessem expressão pecuniária ou econômica, a exemplo dos direitos da personalidade, que apenas receberam aquela tutela legislativa com a Constituição de 1988 e o CC de 2002. (LÔBO, 2018, p.18.)

A inversão do objeto de tutela decorreu da necessidade de harmonizar as normas civis e constitucionais.

O Direito Civil, ao longo de sua história no mundo romano-germânico sempre foi identificado como o locus normativo privilegiado do indivíduo enquanto tal. A partir do constitucionalismo moderno, nenhum ramo do direito ficou mais distante da constituição do que ele. Em contraposição à constituição política, era cogitado como constituição do homem comum, máxime após o processo de codificação liberal. (LÔBO, 20118, p.50)

A lógica subjacente a essa desconstrução jurídica e reinvenção é que o patrimônio passou a não gozar de autonomia, desta feita, servindo à pessoa. O Direito Civil não é atemporal. As relações sociais não são estáticas. O constitucionalismo moderno e seus princípios ético-políticos reitores, acentuaram uma distância já escarpada entre o Estado e a sociedade civil, o que reclamou uma renovação paradigmática e conceitual. "Antes havia a disjunção; hoje, a unidade hermenêutica, tendo a constituição como ápice conformador da elaboração e da aplicação da legislação civil. " (LÔBO, 20118, p.50)

A constitucionalização das relações jurídicas possui uma tônica humanística, não desnaturando a essência dos Institutos do Direito Civil. Essa apropriação valorativa afigura-se essencial à promoção da dignidade e isonomia nessas relações, alicerce do Estado Social e Democrático de Direito. A interlocução entre as fontes normativas, constitucional e infraconstitucional, enseja a harmonia e a racionalidade hermenêutica do ordenamento jurídico, tornando efetiva a incidência dos direitos e garantias fundamentais nos relacionamentos interprivados. A interpretação não é um processo neutro, mas, lógico, valorativo, cultural e ideológico, que se organiza a cada leitura.

Nesse cenário de transformação, a família moderna se estruturou a partir da Constituição cidadã com o reconhecimento da família plural, independentemente:1-do modus de formalização e registro (casamento, união estável e, até mesmo, a monoparentabilidade familiar); 2-da concreção da igualdade jurídica entre seus membros e; 3-da consagração dos princípios da dignidade, realização da pessoa humana, da solidariedade e, por derradeiro, do implícito direito à felicidade. Esses três eixos compõem a viga mestra da codificação do Direito da família, quadro que ascendeu o afeto a condição de valor jurídico. A filosofia pluralista, ao abrigar-se sob o manto do Estado Democrático de Direito e superar o patriarcalismo, passou a comportar arquétipos familiares distintos.

A diversidade dos módulos familiares da multifacetada sociedade brasileira deu start à reorganização estrutural, ética e moral da família, a despeito da resistência conservadora. Os 
arranjos familiares emergentes e sua composição diversa exigiram uma adequação do Direito à realidade posta, fomentado, em parte, pelas controvérsias oriundas da aplicação da própria lei e pela falência do modelo tradicional. (SOUSA e WAQUIN, 2015; MIRANDA, 2009)

A moldura familiar clássica, historicamente construída, alimentou-se de uma representação patriarcal, parental, preconceituosa, excludente, monogâmica e funcionalmente hierarquizada, baseada na desigualdade e, em alguns casos, nas relações meramente patrimoniais. Afinal, casamentos eram firmados por acordos com motivação econômica e política, em uniões meramente institucionais e desprovidas de afetividade (supremacia de interesses negociais). Nesse contexto de mudança, a família brasileira foi ressignificada e repersonalizada em torno do afeto, amálgama dos relacionamentos interpessoais. Com efeito,

Tais transformações levaram à construção das famílias contemporâneas, fundadas no afeto, na solidariedade, no respeito mútuo e na construção da felicidade individual, base para o atual enlace familiar. É, sem dúvida, uma grande modificação na família, a alteração do tipo de vínculo relacional existente entre seus membros, que passou de religioso, para patrimonial e, por fim, afetivo. (SILVA, 2019, p.25)

A família perdia, então, a função política de outrora, inspirada no Direito Romano, para tornar-se uma célula endógena do ambiente privado. O advento da constitucionalização do Direito Civil espargiu os ecos dos princípios da carta política aos institutos da família, impondo restrições à autonomia de particulares, ao mesmo tempo que incitou preocupações com a convivencialidade e a fraternidade no âmbito das relações familiares. Essa transição paradigmática afastou o ramo da privatização dessas células sociais, por meio da excessiva contratualização das relações, a prejuízo dos vínculos afetivos. (MORAES, 2013)

O Direito de família, na atualidade, lida com variadas pressões: a preservação da autonomia da vontade do ente particular, o dever de tutela aos hipossuficientes, as macrodiretivas constitucionais, os anseios da sociedade em transformação e a demanda pulsante por justiça, que conecta as diferentes pautas e atores sociais. Esses vetores, por conseguinte, tem exigido e até provocado, intensa produção doutrinária. Impende salientar o efeito dessas releituras e da elaboração jurisprudencial que, em harmonia com a base principiológica constitucional, deslocaram a atenção do objeto de direito para o sujeito (valorização da pessoa). Esse cenário, por certo, revolucionou os critérios hermenêuticos.

Essa breve exposição introduz o fenômeno da constitucionalização do Direito Civil e a sua ressonância no âmbito do Direito de Família, especificamente, nos casos de abandono afetivo. Por esse prisma paradigmático, problematizou-se: Juridicamente, a afetividade pode ser considerada um dever parental? Complementarmente, qual a dimensão ou quais os contornos do dever jurídico de cuidado e a definição do abandono afetivo? Impõe-se ainda como reflexão: A afetividade pode ser objeto de controle, disciplina e coerção pelo Direito? Nesta discussão considerou-se como caso paradigma o Acórdão proferido pela $3^{\text {a }}$ Turma do Superior Tribunal de Justiça, quando do julgamento do RESP 1.159.242, analisando sua ressonância em outros julgados.

Ressalte-se que, por esta análise e argumentação, que não se advoga em favor da desproteção, mas, tão somente, uma reflexão atenta acerca dos limites do Direito em demandas que tratam sobre sentimentos e processos emocionais, até mesmo porque a concepção de afeto não se confunde com cuidado, cuja regularidade, nas perspectivas sócio e biocultural, afigura-se como consequência espontânea, apesar de tratar-se de atitude omissiva socialmente reprovável. Ademais,

(...) mostra-se evidente que sempre existirão pais, concretamente considerados, que não estarão capacitados a direcionar verdadeiro afeto aos seus filhos, seja por inabilidade, seja por compromissos excessivos assumidos em outras áreas da vida ou seja ainda em razão de evidentes desvios de personalidade que o impedem de 
demonstrar o necessário cuidado emocional que um ser humano em formação necessita. (FERREIRA NETO e EICKL, 2015, p. 221)

Afinal, quais os marcadores da afetividade? Se esta resposta demanda interlocução com outras áreas, o Direito não dá conta da problemática posta. O meio de correção pelo Direito, reparação pecuniária, restaura ou restabelece a relação ou, tão somente, serve ao propósito de vingança? Esta é a melhor justiça?

Objetivou-se, nesse intento, analisar o teor dessas posições e, em confronto com as diferentes posições doutrinárias e o caso paradigma, elaborar um entendimento consubstanciado. O corpus da pesquisa compôs-se por sete casos além do caso paradigma.

$\mathrm{Na}$ consecução desse propósito estruturante, optou-se pelo estudo multicascos, ${ }^{1}$ procedendo-se a uma sistemática análise documental amparada em acórdãos judiciais sem recorte de procedência, referenciados no decurso do trabalho, e na literatura especializada. Trata-se de “(...) método imersivo de pesquisa que visa à exploração de um objeto bem delimitado, que pode ser uma realidade, uma organização, ou situação-problema. " (VASCONCELOS et al, 2015, p. 49)

Naturalmente, por força de sua natureza, as pesquisas baseadas em estudos de caso não têm por objetivo a abrangência ou a formulação de padrões decisionais, visando tão somente a profundidade de abordagem, o que confere aos estudos, a qualidade de intensidade. (YIN, 2001)

"Mediante um mergulho profundo e exaustivo em um objeto delimitado, o Estudo de Caso possibilita a penetração em uma realidade social, não conseguida plenamente por um levantamento amostral e avaliação exclusivamente quantitativa. " (MARTINS, 2008, p.9)

Nesse percurso, é oportuno destacar que esta investigação explorou tão somente a lógica da construção desses discursos nos enunciados das citadas fontes, sem adentrar em juízos morais ou sentidos ocultos. (MOREIRA e TONELI, 2014)

Pesquisa qualitativa, esta investigação é meramente exploratória, não se prestando à finalidade de generalização. Respeitou, portanto, uma lógica indutiva, cujos desdobramentos derivaram da análise de conteúdo dos casos tomados como amostra. (GRAY, 2012) A discussão de resultados, com fulcro teórico-dogmático, será apresentada na seção temática que trata acerca da matéria de modo contextualizado, a partir dos diferentes eixos: o princípio da afetividade e a exigibilidade do afeto, o abandono material e afetivo e a tendência dos julgados. Não obstante o Superior Tribunal de Justiça venha progressivamente firmando o entendimento de que a ausência de afetividade no núcleo familiar não pode ser tratada como ato ilícito reparável pecuniariamente, a divergência sobre o tema persiste, quadro que fomenta fecundo e animado debate, o que motivou a realização deste estudo.

\section{DIGNIDADE DA PESSOA HUMANA}

O conceito de dignidade humana tem como esteio a autonomia e demais formas de liberdade. Essa autonomia, entretanto, não é irrestrita ou indefinida, sendo determinada, muitas vezes, pela condição de coexistência social e preservação dos direitos fundamentais da coletividade (valor comunitário), tutela que assegura a civilidade nas relações. A dignidade como valor comunitário se impõe quando da necessidade de se contemplar, em análise, a primazia de valores compartilhados a interesse da sociedade. (NUNES, 2010)

O próprio conceito de 'propriedade', instituto do direito público, tem sua aplicação conformada pelo princípio da dignidade humana em sua acepção de 'valor comunitário'. Essa constrição externa da autonomia do indivíduo é realizada para: assegurar direitos fundamentais em situações concorrentes; proteger a pessoa de si mesma e; impor valores sociais significativos. Significa dizer que a proteção da propriedade deixou de ser o fim maior, mas tão somente meio para efetivação da justiça social e bem comum. (SOARES, 2010)

\footnotetext{
${ }^{1}$ Método empírico de investigação apropriada quando se objetiva explorar um fenômeno contemporâneo sem deslocálo de seu contexto e lugar na vida real.
}

Revista de Direito Brasileira | Florianópolis, SC | v. 26 | n. 10 | p. 387-409 | Mai./Ago. 2020 
O Direito se socorre da vagueza do princípio da dignidade humana para buscar nos desacordos litigiosos abrigo para casos complexos, não uma solução objetivamente correta, mas uma solução possível, considerando a perspectiva do julgador.

"Pensar a Constituição Federal como norma matriz, que edifica todo o ordenamento jurídico brasileiro em um sistema de simbiose entre regras e princípios, constitucionais e legais, não é lugar comum, tampouco mero argumento de retórica. " (SCORSATO, 2010, p, 90)

No âmbito do Direito de família, o princípio da dignidade humana teve como alcance imediato a preservação das identidades e identificações dos membros desses núcleos, independentemente dos parâmetros étnicos, de gênero, de vínculo, ou mesmo, de origem. De plano, desconstruiu-se a hierarquia presente em arquétipos familiares verticalizados, assegurando-lhes tratamento igualitário. A concepção de família foi ressignificada, ascendendo a um novo paradigma, que se compõe por conforto psicológico, integração, acolhimento, autonomia e afetividade, enfim, por condições existenciais mínimas. A cidadania plena não estava sob o usufruto exclusivo do patriarca, mas de todos aqueles que integram o núcleo familiar. Resta inequívoco que o princípio da dignidade humana viabiliza as condições de tutela desse ramo do Direito, ampliando o espaço de atuação do Estado visando a proteção eficaz da pessoa humana.

Nessa esteira de compreensão, a recepção das diretivas constitucionais pelo Código Civil se impõe como desafio no tocante à operacionalização do princípio no ramo. Ainda que o espaço privado das famílias mantenha suas reservas de intervenção estatal, abusos, cerceamentos e subjugações, não são admitidas, violações que autorizam a atuação do poder público nesse âmbito.

\section{CONSTITUCIONALIZAÇÃO DO CÓDIGO CIVIL}

O advento da promulgação da Constituição cidadã produziu inequívocos reflexos à praxis do Direito privado, precisamente no espaço das liberdades individuais. Apesar da obviedade da interferência fundante da CF na autonomia privada, verificou-se alguma resistência de civilistas à constitucionalização do Direito privado (para adequação aos fundamentos da república). Essa inquietação se alicerçou no entendimento de que a interferência sobredita fragilizaria a dogmática do Direito privado. Ocorreu, porém que, contrariando as expectativas, não se deu a diminuição do espaço de incidência, mas tão somente um necessário redimensionamento, com vistas à concretização e compatibilização dos valores constitucionais àqueles ínsitos às normas do Direito civil.

A incorporação das diretivas da Constituição à atividade hermenêutica na praxis civil constituiu um marco natural e relevante de transição. A apropriação desses paradigmas axiológicos à interpretação e aplicação da norma incidiu em todos os ramos. A imprecisão e inclusividade dos princípios não lhes tirou a força prescritiva, muito menos o alcance. A apropriação dos princípios constitucionais é coerente com a própria estrutura de ordenamento: una, complexa e indivisível.

$\mathrm{O}$ ordenamento, como o próprio nome sugere, consiste em um conjunto de normas dispostas de modo sistemático, harmônico e lógico, com a função de ordenar a vida em sociedade. Esse complexo normativo não se restringe ao direito positivo. O conjunto de diretivas legais forma um todo orgânico, heterogêneo, axiológico, prescritivo, hierarquizado, monolítico, aberto, mas com cerne na Constituição, que corresponde a uma tábua de valores que identifica culturalmente a sociedade. Significa dizer que o ordenamento não é um modelo binário (público/privado). (BOBBIO, 2014)

A natureza aberta dos princípios constitucionais favorece a apreciação de novos interesses e situações jurídicas, ensejando a adequação das decisões às peculiaridades de cada caso concreto. Nesse diapasão, as linhas divisórias ou classificações são meramente conceituas, porque na prática o sistema normativo é demasiadamente imbricado. A abstratividade fornece um campo aberto para contemplação dos vetores indutores de comportamentos sociais, ou onde se verificar qualquer lacuna normativa. 
O código de 1916, com suas normas fechadas, tinha como missão assentar e garantir a estabilidade jurídica, tutelando direitos reclamados pelos burgueses após a revolução francesa. Após o sancionamento da Constituição Federal de 1988, o código civil distanciou-se desta significativamente, não somente pelo lapso temporal e mudanças sociais, mas por serem diplomas frutos de momentos históricos distintos. Dessume-se dessa breve argumentação, que o Código Civil de 1916 não mais dava conta desses novos fatos e interesses, muitos dos quais existenciais.

O Código Civil foi produzido em contexto e épocas diferentes, no que culminou uma codificação nos moldes liberais, processo influenciado pelos marcos históricos das revoluções americana e francesa, referência que beneficiou a um público bem específico: a burguesia ascendente. E assim, a 'sociedade civil e o 'Estado' foram situados política e juridicamente em espaços separados de poder, devidamente demarcados. Os espaços público e privado, no Estado liberal, atuavam em esferas não comunicantes. O código civil servia ao amparo dos negócios, sendo considerada a Constituição das relações privadas, característica que o isolava completamente. As Constituições ditas liberais não regulam as relações no âmbito privado, operando como estado mínimo. (FIGUEIREDO, 2014)

Com efeito, a codificação nos termos liberais serviu aos propósitos de exploração, agravando o status de desigualdade social e de conflitos políticos. Esse cenário deu ensejo ao Estado social e ao consequente alargamento de suas responsabilidades, ampliando, inclusive, a competência revisional dos magistrados. De ponto de vista prático, essa disjunção histórica prejudicava a unidade do ordenamento (perspectiva hermenêutica), restando, portanto, inequívoca incoerência, uma vez que o Código Civil deve ser 'lido' a partir das diretivas constitucionais, constatação que oportunizou os esforços de constitucionalização do ramo. (LÔBO, 2018.)

A contextualização e relativização dos direitos privados se colocaram, então, como demanda emergente e necessária à realização da justiça social, vinculando às suas ações, valores éticos e humanísticos. Por esse olhar e novo paradigma, a atuação do Estado visava coibir abusos de toda natureza (políticos e econômicos), tornando o espaço público um ambiente de afirmação da dignidade e igualdade, com respeito ao pluralismo social em ampla acepção. (LÔBO, 2018.) A valorização da separação do público e privado, apesar de reducionista e fortemente criticada, ainda é observada na atualidade, o que é contraditório porque não é a cogência de uma norma ou a intervenção do Estado que define e identifica uma relação jurídica como 'pública'.

É fato que uma das dicotomias mais resistentes do sistema jurídico é aquela que secciona o Direito em público e privado, como necessidade de definir os espaços de poder, protegendo algumas relações de interferência do Estado, âmago da concepção liberal. O capitalismo se nutriu desse pensamento e estrutura, formando o Estado liberal cuja marca foi a não intervenção estatal, limitando-se a aplicar a lei. Realmente, em plano inicial, o Estado não intervinha na relação entre particulares. Ocorreu que esse modelo entrou gradativamente em crise, fazendo surgir o Estado Social, marcado pela intensificação da intervenção estatal com o propósito de promover a justiça e reduzir desigualdades. (FLEINER-GERSTER, 2006)

A Constituição Federal de 1988 tem como paradigma político o Estado social e democrático de direito, no que implica o reconhecimento das liberdades, da dignidade humana e da igualdade, em vista da demanda emergente da protagonização do cidadão no processo político e jurídico da nação, com redução da discricionariedade do julgador. (TEIXEIRA, 2012)

À época, era evidente a necessidade de interlocução do Direito Civil com outros ramos e saberes jurídicos, da demanda por maior integração e interdisciplinaridade interna, igualmente, do reconhecimento e apropriação dos fundamentos constitucionais, que na verdade afigura-se como parâmetro de validade jurídica.

A elevação dos fundamentos do Direito civil ao status constitucional foi uma deliberada escolha axiológica da sociedade, indispensável para a consolidação do Estado Democrático e social do Direito e consequente promoção da justiça social 
e da solidariedade, incompatíveis com o modelo liberal anterior de distanciamento jurídico dos interesses privados e valorização do individualismo. (LÔBO, 2018, p.55)

O aludido processo de constitucionalização do Código Civil compatibilizou os diplomas, resgatando e incorporando os princípios e valores da Carta Magna. O estatuto em tela passou, então, a assentar-se na preservação da dignidade humana, mínimo existencial invulnerável, valor espiritual e moral. Como princípio e regra constitucional, a dignidade se impôs como pilar fundamental do Estado democrático de Direito. A preservação da dignidade humana despontou, destarte, como o fim maior do ordenamento, extrapolando seus limites, impondo-se como imperativo ético-existencial. (SCORSATO, 2010) Antes da vigência da Constituição Federal de 1988, o julgador desprestigiava forçosamente o contexto e determinantes de ocorrência do caso concreto e seu conteúdo axiológico ínsito ao paradigma de justiça. O Direito romano, principal influência do Direito brasileiro, mostrou-se insuficiente à lógica de acumulação capitalista porque era voltado para a segurança jurídica, estabilidade e justiça social. A letra da lei era interpretada de forma literal, com precisa objetividade, geralmente, a prejuízo das partes hipossuficientes das relações jurídicas, o que comprometia a consecução da missão social do Direito.

No decurso do tempo, o Direito Civil Constitucional configurou-se como fenômeno misto, normativo e doutrinário, onde as mudanças verificadas no Código também foram motivadas pela flagrante desatualização de suas normas, distantes da realidade social para a qual vigoraria. Basta dizer que o Código Civil invisibilizava a mulher em seu texto, inflexibilizando também as condições de dissolução das relações matrimoniais, reflexo do individualismo jurídico. Esse paradigma, naturalmente, atingiu esgotamento, posto que não dava conta de situações do cotidiano e demandas progressistas da época.

Importa destacar que a mudança resultante não foi episódica ou meramente circunstancial, mas histórica e continuada, não obstante se reconheça a resistência por parte dos civilistas, que temiam a fragilização da dogmática civil e com esse ânimo, advogavam a centralidade do Código e autonomia da iniciativa privada. (TEPEDINO, 2000)

A constitucionalização do Código Civil foi um movimento efetivo de descodificação e recodificação com vistas à necessária atualização do diploma a partir da releitura dos princípios e valores constitucionais na consolidação de uma sociedade livre, mais justa e solidária. Essa interlocução desconstruiu a apenas aparente autossuficiência da norma civil. Todavia, parafraseando Serejo (2018), não se discute o 'lugar' do Direito de família no Direito privado, a despeito da sua sui generis aproximação do Direito público. Não é sem razão que se preserva o Direito de família mínimo, reconhecendo-se o Direito Constitucional da família. (SEREJO, 2018)

A referida separação dos espaços, público e privado, ainda resiste, mas com função meramente operacional. A renovação dos direitos (os 'novos direitos') tem produzido uma maior interlocução entre esses setores, os ramos do Direito e a sociedade. Dentre os ramos jurídicos, o Direito Civil e a Constituição são os mais presentes no cotidiano do cidadão, o que corrobora essa necessária aproximação. A codificação civil individualista orbitava em torno do patrimônio e interesses das forças econômicas e políticas hegemônicas (tradição patrimonialista), tornando secundária a pessoa humana. Como decorrência da repersonalização do Direito Civil, o princípio da dignidade humana passou a ser invocado amplamente nas argumentações e jurisprudência dos tribunais. Tratar da repersonalização do Direito Civil reclama uma breve exposição sobre o direito à propriedade, que ocupava centralidade na codificação que precedeu a atual.

Após o advento da Constituição cidadã, o exercício do direito à propriedade ficou condicionado à consecução de sua função social, por meio do reconhecimento do direito ao acesso a propriedade digna e aquele das cidades, humanizando as respostas jurídicas às questões sociais postas. A função social da propriedade se impôs como um elemento conformador de seu conteúdo, tornando secundária a tradicional titularidade jurídica, com vistas a promover a igualdade material. De fato, o direito à propriedade está intimamente associado ao conceito de dignidade, dada a sua

Revista de Direito Brasileira | Florianópolis, SC | v. 26 | n. 10 | p. 387-409 | Mai./Ago. 2020 
indispensabilidade para a concretização de uma vida digna. Entretanto, a questão ainda constitui motivo de tensão quando da interpretação da norma constitucional porque, ao mesmo tempo em que garante o direito à propriedade (demanda individualista), impõe que esta atenda a uma função social (dimensão solidária), restringindo a autonomia ínsita à prerrogativa.

A antinomia aparente dos dois incisos do artigo $5^{\circ}$. da $\mathrm{CF}$, que disciplina sobre a matéria, foi superado pelo aporte dos princípios constitucionais, especialmente aquele da dignidade humana. Numa interpretação literal e isolada, com a necessária vênia para uma breve digressão, o direito à moradia concorre com aquele da propriedade, relativizando a concepção de propriedade a partir dos critérios 'ocupação' e 'utilidade'. A busca por um conteúdo mínimo, com grau de densidade jurídica e objetividade operacional afigurava-se como um desafio hermenêutico. De fato, no cotidiano dos tribunais, reclama um sentido objetivo para a dignidade humana para uniformização da aplicação operacional, pois, o princípio é amplamente invocado na fundamentação de suas pretensões, muitas vezes, em posições contrapostas numa mesma lide.

Com a ingressão da constitucionalização do código civil, os direitos da personalidade ganharam relevo nas decisões. Os contratos passaram a ser revistos sob a métrica da equivalência material, coibindo a onerosidade desmedida. Os contratantes tiveram sua liberdade para contratar circunscrita aos limites da função social do contrato.

Não obstante a propriedade e o contrato sejam institutos do Direito civil com natureza patrimonial, o que se discutia à época era a prevalência da concepção patrimonialista sobre a dignidade da pessoa humana, o que obstaculizava a busca pela concretização da igualdade material e do princípio da solidariedade social na aplicação do Direito ao caso concreto. Questionava-se, portanto, o sentido dessa primazia, que afastava o direito do paradigma de justiça, embora não restasse dúvidas de que a democracia se realiza por meio da solidariedade social e dignidade humana. Essas tensões alcançaram os diferentes ramos do Direito.

A ampliação da concepção social de família, impulsionada pelo reconhecimento legal das identidades e união homoafetiva, redefiniu papéis cristalizados na sociedade, realizando em plano concreto, o princípio da dignidade humana com toda a sua força normativa. O Direito sucessório, primando pela solidariedade das famílias (funcionalizadas à realização da dignidade) e assistência adequada de seus entes, expandiu os vínculos de pertencimento, alcançando aqueles extraconjugais. O Direito de família trouxe o reconhecimento da paridade dos cônjuges nos contratos de casamento, panorama que ensejou igualdade jurídica, vertendo valores há tempos reclamados pela sociedade. (MORAES, 2013)

A repersonalização dessas relações civis foi fruto da própria emancipação do cidadão, pois, sua patrimonialização tornou-se insustentável para a sociedade. De fato, a Carta política de 1988 relevou, à condição de diretivas jurídicas norteadoras, a dignidade da pessoa humana, igualdade e solidariedade, o que oportunizou a garantia da liberdade da formação familiar. "Abriuse, assim, espaço para a família eudemonista, que se funda nos laços de afeto e na realização pessoal de cada membro." (SILVA, 2019, p.19)

Os ecos da repersonalização do Direito Civil encaminharam à conformação do instituto familiar, em contracorrente aos costumes da sociedade brasileira com identidade patriarcal, patrimonial e de papéis hierarquizados historicamente constituídos. Esse quadro foi forjado e catalisado pela expansão do movimento feminista, a disseminação de meios de controle reprodutivo, a inserção da mulher no mundo do trabalho, a industrialização e consolidação do Estado Democrático do Direito, panorama que ressaltou a importância do afeto, do respeito e cuidado nos relacionamentos interpessoais. A reflexão que se impõe é se a afetividade é passível de coerção judicial ou meramente de reprimenda moral. (MORAIS, 2013; SILVA, 2019; SOUSA e WAQUIM, 2015)

Em tempos de "individualismo sem subjetividade", onde a pessoa é invisibilizada pelo processo de massificação social que a reduz ao indivíduo que consome, o desafio que se impôs aos civilistas foi resgatar a dimensão ontológica do sujeito de direitos, restaurando a primazia do 
humano nas relações jurídicas à custa da desconstrução do individualismo patrimonialista presente no ideário liberal. As diretivas constitucionais, além de oferecer moldura à interpretação dos fatos, especialmente os hard cases, têm incidência direta quando da inexistência da norma infraconstitucional para a solução dos conflitos que chegam aos tribunais.

\section{DIREITO, FAMÍLIA E AFETIVIDADE}

Realidade sociológica, a família representa um conceito em transformação. Na Antiguidade Clássica, o elo de constituição familiar era a religião e seu culto ritualístico aos deuses domésticos, denominados de manes, antepassados desses núcleos.

Era um tempo em que a adoção não só era bem aceita como incentivada, para preservar a adoração dos ancestrais. Por meio do casamento, a esposa abandonava os seus antepassados e passava a cultuar os manes de seu esposo, não existindo a possibilidade de cultuar duas linhagens de deuses, o que significaria pertencer a duas famílias. (SOUSA e WAQUIM, 2015, p. 72-73)

Os filhos (varões), quando do falecimento do patriarca, assumiam o controle do núcleo (pater famílias), marco fundante do patriarcalismo. Somente o parentesco paterno produzia efeitos jurídicos. O communi jure, árvore genealógica de afiliação paterna, produzia os únicos vínculos jurídicos reconhecidos. No decurso do tempo, o vínculo religioso perdeu significado e força na formação das entidades familiares, sendo superado muito depois, por aquele cognatício ou biológico. Antes, porém, o instituto passou a referir-se ao conjunto de escravos, propriedade de determinada pessoa. Para esse grupamento, entretanto, não se requeria qualquer vinculação biológica ou mesmo afetiva, sequer a condição marital era exigida para constituição do núcleo familiar na acepção da época. A própria origem da palavra (famulus) faz alusão a condição de escravos domésticos, inclusive, titularidade transmitida por testamento. (SILVA, 2019)

No cenário do Direito Romano, permaneceu a figura do paterfamilias - o patriarca. O patriarca adquiria bens e administrava o patrimônio familiar (domenica potestas), exercia o poder sobre as pessoas dos filhos (patria potestas), sobre a mulher (manus) e sobre os escravos (dominica potestas), ou seja, centralizava a autoridade familiar e patrimonial. (SOUSA e WAQUIM, 2015, p. 73)

$\mathrm{Na}$ antiga Roma, as famílias podiam ser comparadas a associações religiosas, destinada à realização de culto aos antepassados, cujas súplicas visavam a prosperidade, a proteção nos diferentes âmbitos, além de campos férteis. A economia da época era essencialmente agrícola. A religião era professada nos lares, embora os rituais fossem diferentes. A liberdade de culto e o respeito à crença eram marcos distintivos da época. Acrescente a essa análise a informação de que "O Pontífice de Roma ou o arconte de Atenas podiam unicamente, verificar se o pai de determinada família estava cumprindo os rituais, não possuindo o poder de modificar o ritual doméstico. " (SILVA, 2019, p.27)

O patriarca acumulava os papéis de chefe familiar, religioso e político, fazendo suas próprias regras de governança. Os descendentes tinham a missão de dar continuidade à religião. Esse momento histórico gestou o conceito de pátrio poder (pater potesta), absoluto e ilimitado no âmbito das famílias. Esse poder irrestrito patrocinava uma série de abusos, a exemplo do direito de não reconhecer seus filhos, de emancipa-los, abandonar a esposa estéril ou adúltera (dissolução de casamentos) e acordar casamentos. A hierarquia familiar destacava o homem, invisibilizando e subjugando a mulher (esposa e filhas). O casamento consistia em um dever religioso, não necessariamente baseado em afinidade, prazer ou amor. Não se pode afirmar a inexistência de afeto, mas, certamente, esse não tinha qualquer ressonância sobre o Direito. Os núcleos familiares

Revista de Direito Brasileira | Florianópolis, SC | v. 26 | n. 10 | p. 387-409 | Mai./Ago. 2020 
eram, na verdade, unidades produtivas, também destinadas à procriação (legítima). Com o advento do Cristianismo, o Instituto passou a ser considerado um sacramento, mantendo-se a sua indissolubilidade. (VAQUINHAS, 2017)

Após a revolução industrial, o espaço familiar perdeu a configuração de unidade produtiva e de subsistência, o que deu lugar a relacionamentos mais afetivos e solidários, a despeito de suas características notadamente marcantes: biológica, heteroparental, patriarcal, moralista, institucionalizada, desigual e matrimonializada. A família tornava-se um lugar de referência moral. Esse breve histórico importa à compreensão da tela contextual na qual o Código Civil estava inserido, refletindo o ideário liberal imiscuído ao conservadorismo moral. Realmente, seus dispositivos expressavam a visão estreita da época, especialmente, em relação à mulher, que exercia o pátrio poder apenas em situações excepcionais, quando da ausência do patriarca ou de seus descendentes. (MORAES, 2016)

O fenômeno da industrialização no Brasil produziu significativa demanda por mão de obra e, consequentemente, pela intensificação do processo de urbanização das áreas industrializadas. A família tradicional, matrimonializada e fundada em relações matrimoniais, seguia intacta com suas ranhuras ocultas, mantidas às expensas de um discurso religioso justificador e notada repressão social, inibidora e cerceante. $\mathrm{O}$ véu da religiosidade escondia a subversão de valores de muitos patriarcas, que mantinham relações paralelas ao casamento, criando paradigmas de moralidade sectários.

O patrimonialismo marcava as relações jurídicas nele consagradas. A título de ilustração, na seara dos Direitos Reais, a propriedade era absoluta, um fim em si mesma, garantia inarredável de felicidade (o ter prevalecia sobre o ser). No Direito Contratual, prevalecia aquilo que foi "livremente" pactuado pelas partes (pacta sunt servanda), independentemente da hipossuficiência de um dos contratantes (já que importava apenas a igualdade formal). $\mathrm{O}$ indivíduo, notadamente do gênero masculino, era tido como um ser abstraído de sua condição humana, voltado apenas para a realização de negócios jurídicos (enquanto sujeito de direitos), destacado em conhecidas quatro facetas, a de contratante, proprietário, testador e marido. (ALVES, 2009, p.14-15)

Núcleo social fundamental, as entidades familiares compreendem vínculos e valores complexos, o que reclamou do Direito uma revolução paradigmática. (MACHADO-JIMENEZ, 2014) No Brasil, o modelo legal vigente se assentava em outro instituto, o casamento (religioso ou civil), à revelia da autonomia do sujeito, suas vontades e interesses.

Ainda que boa parte da população não possuísse os recursos financeiros necessários para arcar com os custos da solenidade do casamento, ou que não professasse a fé católica, ou simplesmente não desejasse a autorização do Estado para a constituição de uma família, as entidades formadas à margem da lei eram, da mesma forma, marginalizadas pelos Poderes Públicos, sendo alvo de grande preconceito na sociedade. (SOUSA e WAQUIM, 2015, p.71)

Dessa diretiva legal restritiva decorria que os filhos considerados legítimos eram apenas os que possuíam vinculação biológica com pais casados, sendo considerados espúrios aqueles gerados fora do vínculo marital, estigmatizados socialmente por sua condição. Afastada a legitimidade de afiliação, restava-lhes a pecha de bastardos indignos. A família, por essa lógica instrumental, baseava-se em vínculos obrigacionais legalmente instituídos, não priorizando os laços afetivos, legitimando apenas a procriação e a comunicação do patrimônio aos seus herdeiros. (JARAMILLO SIERRA e ALVIAR, 2015)

O Código Civil de 1916 desprestigiava as famílias informais, marginalizando seus vínculos e frutos. O Estado avançava sobre a intimidade das relações, decretando-as indissolúveis 
e vitalícias. Esse poder de legitimação patrocinou a desassistência dos filhos oriundos dessas relações informais, delimitando, inclusive, o espaço de expressão da sexualidade de seus membros, não obstante a sociedade tolerasse a manutenção dos relacionamentos paralelos àquele matrimonial (autorização implícita para a infidelidade). Ainda que a solidez desses relacionamentos tenha sido meramente aparente, "O discurso de adoção ao princípio da monogamia acompanhou o longo percurso da cristandade do matrimônio monogâmico indissolúvel e destinado à procriação o único espaço da sexualidade." (MADALENO, 2018, p.47). Aos filhos conjugais eram garantidos todos os direitos, restando aos demais preteridos, a discriminação em diferentes níveis, alcançando, muitas vezes, o ápice do abandono afetivo. O Direito não reagia tempestivamente a força dos costumes sociais, negando-lhe, por seu silêncio, a facticidade, condição que refletia uma moral compartilhada artificial e inócua. Divisor de águas, o diploma constitucional deu guarita aos frutos dessas relações paralelas, antes tratados como de segunda classe (ilegítimos), prestando-lhe a justa e devida proteção, alçando-o a condição de sujeitos de direitos. "O patriarcalismo, como se sabe, fundavase na tripla desigualdade de homens em relação a mulheres, de pais em relação a filhos e de heterossexuais em relação a homossexuais. " (MORAES, 2013, p. 558)

As relações informais paralelas eram alvo de ojeriza social, que se estendeu inicialmente as uniões estáveis, consideradas entidades familiares de segunda categoria. Apesar desses entraves culturais, verificou-se acentuada expansão desses relacionamentos em detrimento do casamento civil. (BOCANUMENT-ARBELÁEZ e BETANCUR, 2018)

Embora reste evidente que o modelo familiar clássico (absoluto, totalizante, rígido, monárquico e perpétuo) tenha se fragmentado socialmente, dando lugar a formações mais democráticas e inclusivas, segue resistente o traço do preconceito. (BERNAL GUZMAN, 2015; CATALAN, 2012; CEBALLOS RUIZ, RIOS QUINTERO e ORDONEZ PATINO, 2012 e CIENFUEGOS ILLANES, 2015)

Se no passado, o Estado interferia nas relações familiares por meio das normas de ordem pública (cogentes), cerceando a autonomia privada admitida nas relações patrimoniais e na definição do regime matrimonial; na atualidade, essa intervenção passou a ser autorizada quando identificada a necessidade de proteger seus membros, assegurando-lhes os direitos fundamentais. Por essa lente, os princípios constitucionais alicerçam a autonomia privada com seus valores sociais, importante para a constituição e manutenção de relações hígidas. (ALVES, 2019; TEIXEIRA, 2012 e MANCUSO, 2019) A despeito de todo avanço atinente a identificação da família contemporânea, as características enlaçadas pela doutrina não se mostram exaustivas, muito menos presentes em todos os modelos familiares, o que confere complexidade a essa realidade dinâmica. Destarte,

A nova família foi desencarnada do seu precedente elemento biológico para ceder lugar aos vínculos psicológicos do afeto, consciente a sociedade que, na formação da pessoa humana, os valores como a educação, o afeto e a comunicação contígua guardam muito mais importância do que o elo da hereditariedade. (MADALENO, 2018, p. 46)

De fato, é desejável que a família seja também um lugar de vínculos fraternos, solidários e afetivos, de pertencimento, livre expressão das identidades e identificação, enfim, de reciprocidade e coexistência saudável. Mas, entre as condições ideais e a realidade social existe um hiato, que mobiliza a provocação do Estado visando à tutela dos valores sociais. Sob o manto constitucional, essa intervenção se opera em última instância (ultima ratio), já que as entidades familiares são espaços de liberdade. Objetiva-se, dessarte, preservar a autonomia privada e, por conseguinte, a menor ingerência estatal. (ALVES, 2009; SILVA, 2019; CIENFUEGOS ILLANES, 2015; COSTA. 2008) 


\section{ABANDONO AFETIVO: ANÁLISE DOS CASOS}

A análise das decisões envolvendo abandono afetivo revelou argumentações centradas no dever jurídico de cuidado, o que compreende sustento, guarda, educação, zelo e ampla assistência, não obstante as situações, objeto das ações, tenham como motivo abandono afetivo. Essas demandas são coerentes com a definição contemporânea de entidade familiar: lugar de afeto, de entreajuda e da realização pessoal de seus membros. (ALVES, 2009)

"A família contemporânea encontra sua realização no seu grupo e, dentro deste grupo familiar, cada um de seus integrantes encontra na convivência solidária e no afeto o valor social e jurídico que a família exerce o desenvolvimento da sociedade e do Estado. " (MADALENO, 2018, p. 44-45)

O conceito de família eudemonista está presente, tanto nos entendimentos jurisprudenciais como na produção cientifica. Embora a afetividade não esteja na esfera ou campo de intervenção do Direito, a tutela constitucional deu vazão a pedidos de indenização sob alegação de dano moral decorrente de desamor, como se interferência do Estado tivesse o condão de restaurar esses vínculos, ou ainda, a compensação pecuniária tivesse algum reflexo pedagógico eficaz. Respaldando esse ponto de vista, Refosco e Fernandes (2018) acrescentam que "(...) o trabalho do judiciário não deve se centrar na cura e na sanção do culpado, mas sim na melhoria dos vínculos. " (REFOSCO e FERNANDES, 2018, p.84)

A afetividade, quando se trata de relações familiares, enseja uma compreensão intuitiva (senso comum), apenas subentendida nos enunciados jurídicos, não obstante seja tratada à exaustão pela doutrina majoritária como princípio. O conceito, na atualidade, é parte do mundo normativo (parâmetro metajurídico), embora não o seja em todas as relações interpessoais. Ocorre que cuidado e afeto não têm necessariamente correspondência, dada a impossibilidade de se forçar a expressão desse último.

A manifestação afetivo-emocional decorre do sentimento. Não se força o 'sentir'. O afeto não se define como um potencial inato no âmbito da relação parental, muito menos há que se falar em tendências ou predisposições. (GOMES, 2013; BRAGA e FUKS, 2013; MOREIRA e TONELI, 2015)

Quando se discute a intervenção estatal na tutela dos afetos, que mima e mina o
sujeito entre o desejo e o dever de afeto, é tempo de começar a refletir sobre o que
vem afetando o homem na contemporaneidade à luz da psicanálise; e isso
justamente porque ela enfatiza que o laço social não pode ser considerado, a priori,
como já dado e que a dinâmica pulsional faz interagir forças independentes e
poderosas que lutam entre si, sem conciliação. (BRAGA e FUKS, 2013, p. 308)

Os processos afetivos não se originam da relação jurídica, sendo construídos no decurso da convivência por meio da apropriação dos signos familiares e sua ressignificação, guardando relação direta com as experiências vivenciadas, com as características da personalidade do indivíduo, sua história socioindividual e até, com a própria dinâmica dos relacionamentos naquela célula social. Pensar diferente, “(...) reforça a ideia, ainda presente, de que os afetos acontecem separados das demais funções psíquicas que conformam a personalidade humana. " (GOMES, 2013, p.510)

O afeto possui dimensão plúrima, fortemente marcada por fatores psicológicos, o que lhe confere um caráter espontâneo e anímico, não correspondendo a um conceito jurídico. As reações afetivas se situam fora do domínio arbitral do sujeito. Significa afirmar que, dada a complexidade do conceito, dotado de elevada subjetividade, o afeto não deve ser apreciado meramente sob a perspectiva biológica, mas, igualmente, sob aquela filosófica, antropológica e histórico-social. Por esta senda de análise, dessume-se a impossibilidade de aferir as manifestações emocionais, não somente pela dificuldade, mas, pela complexidade e subjetividade do conceito. Cuidado parental 
não se confunde com afeto, embora possa dele decorrer. Não obstante a norma de regência discipline acerca do dever de cuidado, não traz em seu teor qualquer menção acerca do

(...) dever jurídico de o pai manifestar determinado estado anímico emocional em relação aos seus filhos, o qual, supostamente, permitiria fosse quantificado e qualificado pelo direito as atitudes afetivas que deveriam ser praticadas minimamente pelos pais, de modo a criar, no caso de não atendido satisfatório do critério jurídico que avalia a manifestação afetiva do pai para como seu filho, um direito subjetivo do seu descendente de receber determinada reparação pecuniária. (FERREIRA NETO e EICKL, 2015, p. 232)

Racionalizar o afeto impõe um trato de aparência, portanto, não construído ou desenvolvido no decurso natural da relação parental conferindo um verniz de objetividade que não desnatura a essência do sentimento, dito de outra forma, não resgata ou transforma verdadeiramente a relação.

Por este prisma reflexivo, a indenização cumpre funções discutíveis: compensatória, punitiva e dissuasória, conforme as demandas do caso concreto. Ao defender a função compensatória da indenização, admite-se implicitamente um preço para o afeto parental; ao reconhecer a função dissuasória nega-se a cisão decorrente desses processos, que muitas vezes, alarga conflitos $;^{2}$ ao destacar a função punitiva, desconstrói-se toda a atuação dos tribunais no sentido de pacificar as entidades familiares, a bem da higidez e dignidade de seus membros.

As tentativas de se impor o afeto às relações representam um cerceamento da liberdade de 'sentir', violação inequívoca de direito personalíssimo, não passível de coerção. A argumentação dos julgados analisados se encaminham a este entendimento, em contracorrente àquele tomado por paradigma, recorrentemente citado como fundamento nas ações de abandono afetivo.

De fato, o caso 1 agrega argumentos a essa posição:

CIVIL DIREITO DE FAMÍLIA. RESPONSABILIDADE CIVIL SUBJETIVA. GENITOR. ATO ILÍCÍTO. DEVER JURÍDICO INEXISTENTE. ABANDONO AFETIVO. INDENIZAÇÃO POR DANOS MORAIS. 1. Não ofende o art. 535 do CPC a decisão que examina, de forma fundamentada, todas as questões submetidas à apreciação judicial. 2. A ação de indenização decorrente de abandono afetivo prescreve no prazo de três anos (Código Civil, art. 206, § $\left.3^{\circ}, \mathrm{V}\right) .2$. A indenização por dano moral, no âmbito das relações familiares, pressupõe a prática de ato ilícito. 3. O dever de cuidado compreende o dever de sustento, guarda e educação dos fillhos. Não há dever jurídico de cuidar afetuosamente, de modo que o abandono afetivo, se cumpridos os deveres de sustento, guarda e educação da prole, ou de prover as necessidades de filhos maiores e pais, em situação de vulnerabilidade, não configura dano moral indenizável. Precedentes da $4^{\text {a }}$ Turma. 4 . Hipótese em que a ação foi ajuizada mais de três anos após atingida a maioridade, de forma que prescrita a pretensão com relação aos atos e omissões narrados na inicial durante a menoridade. Improcedência da pretensão de indenização pelos atos configuradores de abandono afetivo, na ótica do autor, praticados no triênio anterior ao ajuizamento da ação. 4. Recurso especial conhecido em parte e, na parte conhecida, não provido. (STJ - REsp: 1579021 RS 2016/0011196-8, Relator: Ministra MARIA ISABEL GALLOTTI, Data de Julgamento: 19/10/2017, T4 - QUARTA TURMA, Data de Publicação: DJe 29/11/2017)

\footnotetext{
2 “(...) é limitante falar na existência de um ‘culpado’ quando a família está em conflito e em sofrimento. ” (REFOSCO e FERNANDES, 2018, p. 84)
}

Revista de Direito Brasileira | Florianópolis, SC | v. 26 | n. 10 | p. 387-409 | Mai./Ago. 2020 
A responsabilização guarda relação direta com um encargo ou contraprestação atrelada à violação, ensejando o dever de reparar alguém em razão de prejuízo causado. Pertine, nessa discussão, citar o Art. 186 do Código Civil: “Art. 186. Aquele que, por ação ou omissão voluntária, negligência ou imprudência, violar direito e causar dano a outrem, ainda que exclusivamente moral, comete ato ilícito." (BRASIL, 2002)

Não se nega a importância do afeto para o desenvolvimento do indivíduo, mas é inequívoca a inoperabilidade do Direito nessa esfera. Nessa toada, urge diferenciar abandono material daquele afetivo. O dever de assistência material advém das posições do sujeito nas relações jurídicas, não de eventual vínculo afetivo. Corrobora esse entendimento o fato de alguns pais prestarem ampla assistência financeira ao tutelado sob a condição do distanciamento cotidiano, impostas por motivos alheios à sua vontade. Dessume-se dessa leitura que, não se restitui o que não foi vivenciado, muito menos se restaura laços por força exclusivamente de um imperativo judicial (situação de litigio) ou pressão social, se ausente o despertamento da consciência. Descabe confundir abandono afetivo com a omissão parental ante o dever de cuidado. Assim, esses argumentos vulneram o sentido da imposição legal, sem embargo da vasta produção doutrinaria que exsurge na área jurídica, manifestamente a favor do reconhecimento da responsabilidade civil nesses casos. Fixar o quantum indenizatório pressupõe escalas de afetividade e um gabarito de gestos para dimensionamento ante o desafio do caso concreto e a incidência de excludentes atenuantes. Afinal, o afastamento afetivo pode ser provocado por fatores supervenientes, como ilustra o caso 2 cuja ementa da apelação resta referenciada:

APELAÇÃO CÍVEL. AÇÃO DE EXONERAÇÃO DE ALIMENTOS. PAI BIOLÓGICO. RECONVENÇÃO. FILHA MAIOR DE IDADE. PATERNIDADE SOCIOAFETIVA VOLUNTARIAMENTE ASSUMIDA. EXONERAÇÃO DO ENCARGO ALIMENTAR. ABANDONO AFETIVO. FIXAÇÃO DE INDENIZAÇÃO. DESCABIMENTO. 1. No caso, embora tenha sido reconhecido judicialmente no ano de 2000 o autor como pai biológico da ré, essa realidade não foi levada a registro, sendo afirmada, no ano de 2008 , a paternidade socioafetiva existente e exercida pelo padrasto da ré, que voluntariamente assumiu a condição de seu pai registral, o que se mantém hígido até hoje. 2. Mantida essa realidade de convivência familiar e de relação socioafetiva entre o pai registral e a filha, a exoneração procedida pela sentença vergastada, do encargo alimentar a encargo do pai biológico, é medida que se impõe. 3. As peculiaridades do caso em estudo não evidenciam a ocorrência de omissão voluntária quanto a um suposto abandono moral e afetivo da filha por parte do pai biológico. APELAÇÃO DESPROVIDA, POR MAIORIA. (Apelação Cível No 70073730905, Oitava Câmara Cível, Tribunal de Justiça do RS, Relator: Ricardo Moreira Lins Pastl, Julgado em 05/10/2017).

Alguns afastamentos são circunstanciais e com motivação moralmente justificada, o que requer necessariamente exaustiva contextualização, além de um robusto repertório fáticoprobatório. Sentimentos não são mercantilizáveis e o afeto corresponde a uma expressão desvinculada de intenção, o que, por óbvio, afasta o dolo numa alegada lesão a dignidade do sujeito abandonado. Seara insindicável, se os sentimentos não são exigíveis, não há motivo para se falar em ilícito, mas, tão somente, em reprovação moral. A ilicitude, para fins legais, deve ser uma construção do direito, não da moral, cujos argumentos se somam a motivos religiosos, contaminando o qualificado juízo legal. Nesse intento, há de se distinguir transgressão jurídica daquela moral, essa última passível de reprimenda social. Por essa razão, o afeto não reúne condições mínimas para tornar-se fonte de responsabilização civil, o que restringe sua aplicação às situações de abandono material, uma vez que diz respeito a condutas externas e objetivas. Depreende-se desse breve arrazoado que a mera admissão de expectativas como elementos configurantes de um ilícito é um terreno juridicamente inseguro, sendo inequívoco o risco de 
fomento involuntário à proposição de ações motivadas por razões alheias ao reclamado afeto. A responsabilização civil demanda o respaldo de requisitos autorizantes. Ademais, a dificuldade de se relacionar o dano aos fatores que deram causa enfraquece a argumentação de nexo causal nessas situações.

O caso 3 propõe reflexões pertinentes.

APELAÇÃO CÍVEL. AÇÃO REVISIONAL DE ALIMENTOS C/C INDENIZAÇÃO POR ABANDONO MORAL E AFETIVO. DESACOLHIMENTO DO PEDIDO DE MAJORAÇÃO DO ENCARGO ALIMENTAR E PROCEDÊNCIA DO PLEITO ATINENTE AO DANO EXTRAPATRIMONIAL. APELO DO DEMANDADO. FILHOS QUE IMPUTAM AO PAI O COMETIMENTO DE ABANDONO AFETIVO DECORRENTE DO SEU DELIBERADO DISTANCIAMENTO APÓS FIXAR RESIDÊNCIA NO EXTERIOR E PÔR FIM AO RELACIONAMENTO CONJUGAL. AO PODER JUDICIÁRIO NÃO É DADA A INCUMBÊNCIA DE TUTELAR O AMOR OU O DESAFETO, NUMA ESPÉCIE DE JURISDICIONALIZAÇÃO DOS SENTIMENTOS, QUE SÃO INCONTROLÁVEIS PELA SUA PRÓPRIA ESSÊNCIA A AFEIÇÃO COMPULSÓRIA, FORJADA PELO RECEIO DA RESPONSABILIZAÇÃO PECUNIÁRIA, É TÃO OU MAIS FUNESTA DO QUE A PRÓPRIA AUSÊNCIA DE AFETO. RESPONSABILIZAR, MEDIANTE INDENIZAÇÃO PECUNIÁRIA A AUSÊNCIA DE SENTIMENTOS, É INCENTIVAR A INSINCERIDADE DO AMOR, CONSPIRANDO PARA O NASCIMENTO DE RELAÇÕES FAMILIARES ASSENTADAS SOB OS PILARES DO FINGIMENTO, O QUE NÃO SE COADUNA COM A MORAL, A ÉTICA E O DIREITO. ATO ILÍCITO NÃO CARACTERIZADO. INEXISTÊNCIA DA OBRIGAÇÃO DE INDENIZAR. PRECEDENTES DESTA CORTE E DO STJ. Amor existe ou não existe e, em não existindo, pode até vir a ser cultivado com atitudes de aproximação, jamais sob ameaça de punição. A construção de laços afetivos mediante coação pecuniária é de todo temerária, ressumbrando bizarro imaginar pais que não nutrem afeto algum pela prole, fingirem, de um instante para outro, aquilo que são incapazes de sentir genuinamente, apenas pelo temor de virem a ser condenados a indenizar o que desditosamente já está consumado. Quantos filhos seriam obrigados a compartilhar a presença nociva de alguns pais por força dessa imposição jurisdicional? Guarda alguma razoabilidade imaginar benefícios para o filho quando sua relação com o pai é construída sobre alicerces falsos? Quanto de humanidade realmente restaria de um afeto legalmente conduzido? Em muitos casos, seria ainda de indagar: quantos filhos seriam efetivamente beneficiados pela monetarização do afeto? Para o pai ausente, cujo coração não aflorou para o amor aos filhos, a punição maior está nos dramas da sua própria consciência. É preciso, todavia, saber distinguir a ausência de afeição com a repugnância acintosa. Por isso, em casos excepcionais, onde a falta de afeto criou espaço para um sentimento de desprezo acintoso, de menoscabamento explícito, público e constrangedor, não se descarta a possibilidade do filho pleitear a reparação pelo dano anímico experimentado, porque nesse caso, ao invés da inexistência de amor, não nascido espontaneamente, há uma vontade deliberada e consciente de repugnar a prole não desejada. RECURSO CONHECIDO E PROVIDO. (TJSC - AC: 00262848820138240020 Criciúma 0026284-88.2013.8.24.0020, Relator: Jorge Luis Costa Beber, Data de Julgamento: 07/02/2019, Primeira Câmara de Direito Civil) 
Os casos 4 e 6 trazem situações de ausência justificadas. Estas justificativas têm sido tratadas como 'excludentes de ilicitude', não obstante, a 'ilicitude' de plano afetivo não tenha lugar bem definido no Direito, ou seja, sequer contemplada no Art. 227 da Constituição Federal do Brasil.

Art. 227. É dever da família, da sociedade e do Estado assegurar à criança, ao adolescente e ao jovem, com absoluta prioridade, o direito à vida, à saúde, à alimentação, à educação, ao lazer, à profissionalização, à cultura, à dignidade, ao respeito, à liberdade e à convivência familiar e comunitária, além de colocá-los a salvo de toda forma de negligência, discriminação, exploração, violência, crueldade e opressão. (BRASIL, 1988)

Ressalte-se que a sobredita previsão constitucional releva o cuidado como valor jurídico objetivo, mas não acena para obrigações afetivas.

\section{Caso 4}

APELAÇÃO CÍVEL. AÇÃO DE INDENIZAÇÃO POR DANO MORAL. ABANDONO AFETIVO PELO GENITOR. O réu foi recolhido à prisão três anos após o nascimento da autora e passou a cumprir pena em regime semiaberto um ano depois. Desde então o contato do pai com a autora/filha tornou-se mais escasso, o que deu origem ao alegado abandono afetivo. Contudo, além de o réu não ter abandonado a autora materialmente, pois paga alimentos, não há como imputar ao réu a prática do alegado abandono afetivo, dado o contexto dos fatos. No mesmo passo, não se tem como afirmar que os problemas passados pela criança, hoje com oito anos de idade, decorrem da ausência do pai. NEGARAM PROVIMENTO AO APELO. (Apelação Cível No 70077504041, Oitava Câmara Cível, Tribunal de Justiça do RS, Relator: Rui Portanova, Julgado em 04/10/2018). (TJ-RS - AC: 70077504041 RS, Relator: Rui Portanova, Data de Julgamento: 04/10/2018, Oitava Câmara Cível, Data de Publicação: Diário da Justiça do dia 08/10/2018) Caso 5

APELAÇÃO CÍVEL. AÇÃO DE INDENIZAÇÃO POR DANO MORAL. ABANDONO AFETIVO PELO GENITOR. PRESCRIÇÃO NÃO CONSUMADA. IMPROCEDÊNCIA. 1.Prescrição. Nos termos do art. 197, II, do CC, não corre a prescrição entre ascendentes e descendentes, durante o poder familiar, o qual se extingue pela maioridade (art. 1.635, III, do CC). Logo, considerando que a autora completou 18 anos de idade em 15.02.2014 e a presente demanda de reparação civil foi proposta em 01.06.2015, não há cogitar de prescrição, tendo presente o prazo de 3 anos a que alude o art. 206, $\S 3^{\circ}, \mathrm{V}$, do CC, não implementado. 2. Dano moral. Pretende, a autora, indenização por dano moral, em razão do alegado abandono afetivo do genitor. A prova dos autos, porém, não leva à conclusão de que a conduta do demandado foi capaz de causar dano ou sofrimento indenizável à autora, nos termos dos arts. 186 e 927 do CC. Apesar do pouco convívio entre pai e filha, fruto de relação extraconjugal, o genitor, bem ou mal, prestou assistência material à filha por longos anos, tendo, inclusive, acordado alimentos na presente demanda. A distância entre as cidades, também contribuiu para o afastamento. Além do mais, não restou demonstrado que a ausência paterna gerou na autora lesão emocional e psíquica de tal monta que tenha perturbado seu... estado de bem-estar, comprometendo sua estabilidade e a possibilidade de uma vida normal. Somente em situações excepcionais é que, na seara das relações familiares, se deve conceder reparação por dano extrapatrimonial, sob pena de as pretensões desbordarem para a 
patrimonialização das relações afetivas. Sentença de improcedência mantida. NEGARAM PROVIMENTO. UNÂNIME. (Apelação Cível $\mathrm{N}^{\circ}$ 70076481597, Oitava Câmara Cível, Tribunal de Justiça do RS, Relator: Luiz Felipe Brasil Santos, Julgado em 22/03/2018). (TJ-RS - AC: 70076481597 RS, Relator: Luiz Felipe Brasil Santos, Data de Julgamento: 22/03/2018, Oitava Câmara Cível, Data de Publicação: Diário da Justiça do dia 27/03/2018)

Caso 6

DIREITO CIVIL. AÇÃO DE INDENIZAÇÃO. ABANDONO AFETIVO PELO GENITOR. NEXO DE CAUSALIDADE. AUSÊNCIA. DANO MORAL. NÃO CONFIGURADO. 1. A RESPONSABILIDADE CIVIL EXTRACONTRATUAL, DECORRENTE DA PRÁTICA ATO ILÍCITO, DEPENDE DA PRESENÇA DE TRÊS PRESSUPOSTOS ELEMENTARES: CONDUTA CULPOSA OU DOLOSA, DANO E NEXO DE CAUSALIDADE. 2. AUSENTE O NEXO DE CAUSALIDADE ENTRE A CONDUTA OMISSIVA DO GENITOR E O ABALO PSÍQUICO CAUSADO AO FILHO, NÃO HÁ QUE SE FALAR EM INDENIZAÇÃO POR DANOS MORAIS, PORQUE NÃO RESTARAM VIOLADOS QUAISQUER DIREITOS DA PERSONALIDADE. 3. ADEMAIS, NÃO HÁ FALAR EM ABANDONO AFETIVO, POIS QUE IMPOSSÍVEL SE EXIGIR INDENIZAÇÃO DE QUEM NEM SEQUER SABIA QUE ERA PAI. 4. RECURSO IMPROVIDO. (TJ-DF APC: 20090110466999 DF 0089809-17.2009.8.07.0001, Relator: GETÚLIO DE MORAES OLIVEIRA, Data de Julgamento: 03/07/2013, $3^{\text {a }}$ Turma Cível, Data de Publicação: Publicado no DJE : 16/07/2013 . Pág.: 100)

\section{Caso 7}

DIREITO CIVIL. INDENIZAÇÃO POR DANOS MORAIS. ABANDONO AFETIVO PELO GENITOR. INVIABILIDADE. AUSÊNCIA DE ATO ILÍCITO. MEIO NÃO CABÍVEL PARA COMPENSAR OU SANCIONAR A AUSENCIA DE SUPORTE MATERIAL OU AFETIVO. 1. Incabível indenização por danos morais decorrentes de abandono afetivo quando não for possível aferir-se a efetiva ocorrência de prejuízo moral causado pela ausência do pai ou não comprovado ato ilícito, notadamente porque não restaram violados quaisquer direitos da personalidade. Precedentes do TJDFT e do STJ. 2. O ordenamento jurídico, conquanto possa garantir à autora os direitos decorrentes da filiação, tais como pensão alimentícia, nome, direitos sucessórios - passíveis de obtenção pelas vias adequadas, não exige do genitor a obrigação de amor, carinho e afeto, que são sentimentos que somente se desenvolvem com o convívio no seio familiar, mormente porque a situação delineada nos autos aponta exatamente a dificuldade de aproximação de ambos. 3. Recurso conhecido e desprovido. (TJ-DF 20080710316235 DF 001337163.2008.8.07.0007, Relator: SANDOVAL OLIVEIRA, Data de Julgamento: 06/09/2011, $4^{a}$ Turma Cível, Data de Publicação: Publicado no DJE: 22/09/2011 . Pág.: 123)

Naturalmente, a expectativa social é que tais obrigações jurídicas não se restrinjam ao plano das demandas necessarium vitae (necessidade de alimentos), alcançando a qualidade das relações em plano aberto. Entretanto, a intervenção do Direito reclama atenção às próprias limitações operativas (por exemplo, de constituição de prova da relação causal entre dano psicológico e dano existencial) e estruturais da ciência, especialmente àquelas que dizem respeito ao perímetro disciplinar de atuação, para que não se institua um regime de autoritarismo jurídico, invasivo às liberdades e intimidade do sujeito. As decisões, em sua totalidade, revelaram as dificuldades advindas destas restrições, com reflexo direto no atendimento dos pedidos (casos 5 e 7). 
Tratos motivados exclusivamente por decisões judiciais não dissimulam o que se instala na intimidade da pessoa humana, não desnaturando quem se é verdadeiramente. Enquanto amar é faculdade, o cuidado erige-se como dever.

A convivência forçada, desprovida de afeto, é nociva ao desenvolvimento do indivíduo, demasiadamente lesiva a sua dignidade, restando ao Direito as manifestações exteriores do fenômeno, claramente enunciadas nas normas que contemplam essas violações. De fato, as consequências do (des) afeto fomentam a degradação do clima familiar e, por conseguinte, de precariedade existencial.

As decisões dos tribunais encaminham à relativização dos vínculos, relevando os afetivos sobre aqueles formais ou parentais, nos processos que envolvem adoção, pedidos de guarda, guarda compartilhada, mudança de sobrenome, sucessão, dentre outras matérias. Nos recursos extraordinários n. 646.721, 878.694 e 1.332-773, declarou-se a inconstitucionalidade do Art. 1.790 do Código Civil, equiparando os direitos sucessórios de companheiros e cônjuges, promovendo amplamente a isonomia familiar. Destaque-se o REx n. 898.060, que tem como escopo os direitos dos pais na paternidade socioafetiva e biológica. Nesse ânimo, é incontestável os avanços observados no âmbito do Direito de família no que concerne à tutela dos entes familiares individualmente (proteção dos direitos e garantias fundamentais), o que pode ser evidenciado pelos marcos legais da Lei Maria da Penha, do Estatuto da Criança e Adolescente, da Lei do menino Bernardo e o vasto acervo jurisprudencial.

A doutrina destaca que o abandono afetivo viola diferentes princípios, a saber: da dignidade humana, da igualdade, da solidariedade, do pluralismo das entidades familiares, da afetividade, da paternidade ou maternidade responsável, da isonomia dos filhos, da tutela especial à família, dentre outros (possivelmente). (COSTA, 2008; COSTA, 2016)

Essa apropriação de princípios provoca discussões pertinentes acerca de sua qualificação como tal: princípios (normas), valores ou critérios hermenêuticos? Não se discute a pertinência e relevância da tutela, mas sua justificação inflada em princípios jurídicos.

$\mathrm{Na}$ esteira do que ressalta Streck (2014), entende-se que transformar critérios de interpretação, motivos e valores morais em princípios e, por conseguinte, em direito é criá-lo, consagrando uma discricionariedade tal que pode fragilizar a segurança jurídica. Não obstante se reconheça a importância do afeto nas relações familiares, seu relevo não lhe confere força normativa porque sentimentos não podem ser exigidos, uma vez que fluem em uma esfera que o Estado não pode adentrar e que escapa à técnica jurídica. Elevar um sentimento à condição de princípio jurídico e esvaziá-lo em seu núcleo essencial (jurídico), preenchendo-o com um valor moral.

A imperatividade de uma norma, e os princípios têm força normativa, não podem violar direitos da personalidade. A intervenção estatal pode agravar uma relação familiar já conflituosa. Por essa perspectiva, falta legitimidade ao Direito. Os princípios jurídicos, normas generalíssimas, são diretivas abertas que, em tese, subsidiam os operadores do Direito na solução das situações diversas que reclamam sua atuação, visto que revelam o sentido maior da lei. De caráter deontológico, se situam em um território de abstração imparcial, passível de ser simbolicamente 'deslocado' pelo hermeneuta quando da avaliação do caso concreto. Por essa lente, razão não há para confundi-los com valores sociais. Essas macrodiretivas reitoras integram o universo normativo (do 'dever-ser'), possuindo força vinculante. O Direito se nutre desse caráter para apoiar objetivamente seu processo decisório; já os valores, traduzem conceitos axiológicos, não se traduzindo em comando.

Por fim, o dever de cuidado impõe uma reflexão atenta acerca das condições do sujeito prestador de assistência parental, genitor (a) ou adotante, e das condições que circundam e ambientam a relação, a exemplo do que ocorre nos casos de alienação parental. Essa apreciação deve ser arguida visando considerá-la como excludente. A realidade fática oferece um espectro de possibilidades a partir da conjugação de fatores objetivos e subjetivos conformadores das situações 
levadas a juízo. Naturalmente, o Direito não tolda todas essas variantes, o que estende campo para a discricionariedade do julgador, ainda que não se olvide um núcleo mínimo de assistência parental.

\section{CONSIDERAÇÕES FINAIS}

A constitucionalização da dignidade humana, conceito amplo, relativo, aberto e impreciso, certamente impõe alguma dificuldade na interpretação e sopesamento de direitos quando colidentes, mas, indubitavelmente estende o campo para intervenção judicial, acomodando situações não previstas em lei (os novos fatos do Direito). O evolver dos acontecimentos políticosociais e o afluxo de conflitos são determinantes para a aderência do Direito à realidade social emergente, a despeito da descompassada produção legiferante. De etiologia complexa, as respostas sociais do Direito têm provocado notável projeção do Direito Sumular, que sumarizando entendimentos e decisões, oportunizam a reação tempestiva do sistema processual às novas demandas.

A razão assiste a não aceitação de modelos de família predeterminados pelo Estado, ao revel da existência de outros, pois admiti-lo sem resistência viola liberdades e o direito de afiliação ideológica. A formação familiar genuína após o advento da carta política de 1988 passou a ter sua constituição baseada no afeto, nivelando-se ao clássico vínculo parental formal, visando o melhor interesse da criança e adolescente, consolidando a família como um lugar de convívio respeitoso das diferenças, um ambiente solidário e democrático, sem supremacia de qualquer natureza. Esse deslocamento de eixo, do tradicional para aquele constitucional, tem representado uma revolução de valores, que põe em relevo a dignidade da pessoa humana e o afeto entre os pares no âmbito das relações familiares.

A construção do (des) amor é inacessível a terceiros, escapando ao controle das Instituições. Por essa razão, embora as argumentações postas não remetam a negação da existência do fenômeno-objeto dessa pesquisa, questiona frontalmente o alcance do Direito, que segundo o entendimento delineado, incide apenas sobre a exterioridade do abandono afetivo. E em confluência a esse olhar, as argumentações trazidas nos julgados sublimam àquela jurídica para dar conta da complexidade do fenômeno abandono afetivo.

Por óbvio, as relações afetivas e reações emocionais, não se constituem exclusivamente pela intencionalidade do sujeito (dimensão volitiva), guardando relação com diferentes fatores, a exemplo das identificações, maturidade, afinidades, encantamentos, experiências anteriores, etc. $\mathrm{O}$ indivíduo não controla todas as suas respostas emocionais, razão pela qual o livre arbítrio e a autodeterminação do sujeito não definem os destinatários desse afeto. Esta constatação, iniludivelmente, encaminha ao reconhecimento da inépcia do Direito no que tange a regulação da matéria nesse particular e a responsabilização do 'sujeito que não sente ou expressa adequadamente seus sentimentos'. Ademais, as medidas punitivas não solucionam o alegado abandono, muito menos restaura ou desenvolve afetos, ampliando as fissuras nos relacionamentos intrafamiliares.

Por essa lógica, trata-se de um vetor primário ou gatilho para outras formas de violação cuja responsabilidade civil é cabível (violência física e moral). Acenando para estudos futuros, entende-se como inadiável a problematização acerca dos limites da responsabilidade civil, especialmente nos casos de abandono afetivo, refulgindo a linde jurídica. Dessume-se que os reclamos por assistência se constituem por elementos subjetivos, o que confere forma a um objeto verificável, sem desprestigiar, todavia, os sindicados paradigmas valorativos. 


\section{REFERÊNCIAS}

ALVES, Leonardo Barreto Moreira. Por um direito de família mínimo: a possibilidade de aplicação e o campo de incidência da autonomia privada no âmbito do direito de família. Dissertação (Mestrado) - Pontifícia Universidade Católica de Minas Gerais. Programa de PósGraduação em Direito. Belo Horizonte, 2009.

BRAGA, Julio Cezar de Oliveira; FUKS, Betty Bernardo. Indenização por abandono afetivo: a judicialização do afeto. Tempo psicanal. Rio de Janeiro , v. 45, n. 2, p. 303-321, dez. 2013.

BOBBIO, Norberto. Teoria do ordenamento jurídico. São Paulo: EDIPRO, 2014.

BOCANUMENT-ARBELÁEZ, Mauricio. BETANCUR, Carlos Mário Molina. A estrutura familiar do concubinato: um reconhecimento jurisprudencial na Colômbia. Revista Lasallista de investigación, Colômbia, Vol. 15, n.1, 2018.

BERNAL GUZMAN, Ángela Patricia. La familia como derecho humano de la comunidad LGBTI en colombia. Prolegómenos, Bogotá, v. 18, n. 36, p. 15-28, Julho, 2015. BRASIL, Constituição (1988). Constituição da República Federal do Brasil. Brasília, DF: Senado Federal, 1988.

BRASIL. Lei n. 10.406, 10 de janeiro de 2002. Institui o Código Civil. Diário Oficial da União, Brasília, DF, 11 jan. 2002. Disponível em: . Acesso em: 30 jan. 2011.

BRASIL. Lei n. 8.069, de 13 de julho de 1990. Dispõe sobre o Estatuto da Criança e do Adolescente e dá outras providências. Diário Oficial [da] República Federativa do Brasil. Brasília, DF, 16/7/1990.

CATALAN, Marcos. Un ensayo sobre la multiparentalidad: prospectando en el ayer, pizadas que llevarán al mañana. Rev. Fac. Derecho Cienc. Polit. - Univ. Pontif. Bolivar., Medellín, v. 42, n. 117, p. 581-620, Julho, 2012 .

CEBALLOS RUIZ, Paula Andrea; RIOS QUINTERO, Juliana Victoria; ORDONEZ PATINO, Richard Marino. O reconhecimento dos direitos aos casais do mesmo sexo: o caminho para um conceito de família pluralista. Estudo Socio-Juríd, Bogotá, v. 14, n. 2, p. 207-339, julho de 2012.

COSTA, Welington Oliveira de Souza. Responsabilidade Civil decorrente do Abandono Afetivo. Revista Espaço Acadêmico. n. 176, janeiro / 2016.

COSTA, W. C. N. Abandono Afetivo Parental. In: Sítio Juris Way. Disponível em http://www.jurisway.org.br/v2/dhall.asp?id_dh=784. Acesso em: 30.09.2020.

FLEINER-GERSTER, Tomas. Teoria geral do Estado. São Paulo: Martins Fontes, 2006.

CIENFUEGOS ILLANES, Javiera. Diversidad familiar y derecho en Chile: ¿una relación posible ?. rev.estud.soc. Bogotá, n. 52, p. 159-171, abril de 2015.

FACHIN, Luiz Edson. PIANOVSKI, Carlos Eduardo. A dignidade da pessoa humana no direito contemporâneo: uma contribuição à crítica da raiz dogmática do neopositivismo 
constitucionalista. Revista Trimestral de Direito Civil, v. 9, n. 35, jul./set. 2008, páginas 101 a 120.

FIGUEIREDO, Marcelo. Teoria geral do Estado. São Paulo: Atlas, 2014.

FERREIRA NETO, Arthur M. EICKL, Luciana Gemelli. Abandono afetivo: os limites do direito na coerção de manifestações emocionais humanas. Rev. Direito Econ. Socioambiental, Curitiba, v. 6, n. 1, p. 218-264, jan./jun. 2015

GOMES, Cláudia Aparecida Valderramas. O lugar do afetivo no desenvolvimento da criança: implicações educacionais. Psicologia em Estudo, Maringá, v. 18, n. 3, p. 509-518, jul./set. 2013.

GRAY, David. E. Pesquisa no mundo real. Porto Alegre: Editora Penso, 2012.

JARAMILLO SIERRA, Isabel Cristina; ALVIAR, Helena. " Família " como um conceito legal. CS , Cali, n. 15, p. 92-109, janeiro, 2015.

LÔBO, Paulo. Direito civil: parte geral. São Paulo: Saraiva, 2018.

MACHADO-JIMENEZ, José Alejandro. La transformación del concepto constitucional de familia: alcances de una problemática teórica. Díkaion, Chia , v. 23, n. 1, p. 93133, Junho, 2014.

MANCUSO, Rodolfo de Camargo. Acesso à justiça: condicionantes legítimas e ilegítimas. Salvador: Jus PODIVM, 2019.

MADALENO, Rolf. Direito de família. Rio de Janeiro: Forense, 2018.

MIRANDA, Maria Aparecida Alves de Melo. Registros públicos e as novas entidades familiares. Rio de Janeiro: Publit Soluções Editoriais, 2009.

MORAES, Maria Celina Bodin de; TEIXEIRA, Ana Carolina Brochado. Descumprimento do art. 229 da Constituição Federal e responsabilidade civil: duas hipóteses de danos morais compensáveis. Rev. Investig. Const., Curitiba, v. 3, n. 3, p. 117-139, setembro, 2016.

MORAES, Maria Celina Bodin de. A nova família, de novo - estruturas e função das famílias contemporâneas. Revista Pensar, v. 18, n. 2, p.587-628, maio/agosto, 2013.

MARTINS, Gilberto de Andrade. Estudo de caso: uma estratégia de pesquisa. São Paulo: Atlas, 2008.

MOREIRA, Lisandra Espíndula; TONELI, Maria Juracy Filgueiras. Paternidade, família e criminalidade: uma arqueologia entre o Direito e a Psicologia. Psicol Soc. Belo Horizonte, v. 26, n. spe, p. 36-46, 2014.

NUNES, Rizzatto. O principio constitucional da dignidade da pessoa humana: doutrina e jurisprudência. São Paulo: Saraiva, 2010. 
SCORSATO, Renata Cristina O. Inconstitucionalidade da cláusula de exclusividade nas cooperativas de trabalho médico. POP, Carlyle. PARODI, Ana Cecília. (Coord.) Livre iniciativa e dignidade humana na visão dos tribunais superiores. Curitiba: Juruá, 2010.

SEREJO, Lourival. Direito Constitucional da família. Rio de Janeiro: Lumem Juris, 2018.

SOARES, Ricardo Mauricio Freire. O principio constitucional da dignidade da pessoa humana. São Paulo: Saraiva, 2010.

SOUSA, Mônica Teresa Costa e WAQUIN, Bruna Barbieri. A repersonalização das relações familiares no Brasil. Revista de informação legislativa. Ano 52, n.205, Janeiro/Março de 2015.

STRECK, Lenio. Lições de crítica hermenêutica do Direito. Porto Alegre: Livraria do advogado editora, 2014.

TEIXEIRA, Anderson V. Qual a função do Estado Constitucional em um constitucionalismo transnacional? In: STRECK, Lenio Luiz. ROCHA, Leonel Severo. ENGELMANN, Wilson, Org. Constituição, sistemas sociais e hermenêutica. Porto Alegre: Livraria do Advogado, 2012.

TEPEDINO, Gustavo. Direito civil e ordem pública na legalidade constitucional. B. Cient. ESMPU, Brasília, a. 4 - n.17, p. 223-235 - out./dez. 2005.

REFOSCO, Helena Campos; FERNANDES, Martha Maria Guida. Entre o afeto e a sanção: uma crítica à abordagem punitiva da alienação parental. Rev. direito GV, São Paulo, v. 14, n. 1, p. 79-98, Abril, 2018 .

VAQUINHAS, Irene. As Relações de Poder na Construção do Direito da Família Português (1750-1910). Anál. Social, Lisboa, n. 225, p. 913-917, dez. 2017.

VASCONCELOS, Yumara L. et al. Método de Estudo de Caso como Estratégia de Ensino, Pesquisa e Extensão. UNOPAR Cient., Ciênc. Human. Educ., Londrina, v. 16, n. 1, p. 49-59, jan., 2015.

YIN, Robert K. Estudo de caso: planejamento e métodos. Porto Alegre: Bookman, 2001. 